\title{
Antimalarial plant remedies from Burkina Faso: Their potential for prophylactic
}

\section{use}

\author{
Rakiswendé Serge Yerbanga ${ }^{\mathrm{a}, \mathrm{d}, *}$, Leonardo Lucantoni ${ }^{\mathrm{a}}$, Giulio Lupidi ${ }^{\mathrm{a}}$, Geme Urge Dori ${ }^{\mathrm{a}}$, \\ Nzangue Roselyne Tepongning ${ }^{\mathrm{a}}$, Jean Baptiste Nikiéma ${ }^{\mathrm{c}}$, Fulvio Esposito ${ }^{\mathrm{b}}$, Annette Habluetzel ${ }^{\mathrm{a}}$ \\ a University of Camerino, School of Pharmacy, Piazza dei Costantini, 62032 Camerino (MC), Italy \\ ${ }^{\mathrm{b}}$ University of Camerino, School of Science and Biotechnology, Via Gentile III Da Varano, 62032 Camerino, Italy \\ c Direction de la Promotion de la Médecine et de la Pharmacopée Traditionnelle, Burkina Faso \\ ${ }^{\mathrm{d}}$ Institut de Recherche en Sciences de la Santé, direction régionale de Bobo Dioulasso, Burkina Faso
}

\section{A R T I C L E I N F O}

\section{Article history:}

Received 22 August 2011

Received in revised form

24 November 2011

Accepted 11 January 2012

Available online 25 January 2012

\section{Keywords:}

Plasmodium berghei

Malaria

Traditional medicine

Antimalarial remedies

Prophylaxis

\begin{abstract}
A B S T R A C T
Ethnopharmacological relevance: Saye, a combination remedy prepared from Cochlospermum planchonii Hook.f. (Cochlospermaceae), Cassia alata L. (Fabaceae) and Phyllanthus amarus Schumach. et Thonn. (Euphorbiaceae), N'Dribala, a Cochlospermum planchonii root decoction, and a fruit preparation of Azadirachta indica A. Juss. (Meliaceae) are plant remedies of the folk medicine in Burkina Faso and are commonly used by traditional healers for the treatment of malaria.

Aim of the study: This study aimed at validating the antiplasmodial activity of the preparations and at estimating their potential for prophylaxis, using the murine malaria system Plasmodium berghei/Anopheles stephensi.

Materials and methods: Aqueous extracts were orally administered to mice (6 animals per treatment group) at a daily dose of $200 \mathrm{mg} / \mathrm{kg}$ body weight for nine days, applying protocols that mimic as much as possible traditional recipes and treatment schemes.

Results: Saye, N'Dribala and Azadirachta indica preparations revealed prophylactic activity, reducing parasitaemia in treated mice, with respect to controls, by $52.0 \%\left(\mathrm{Cl}_{95} 46.1-57.9\right), 45.5 \%\left(\mathrm{CI}_{95} 44.5-46.5\right)$ and $45.0 \%\left(\mathrm{Cl}_{95} 41.1-48.9\right)$, respectively. No evidence of transmission blocking effects was detected with any of the tested remedies.

Conclusions: This study confirms, in the murine malaria system, the antiplasmodial properties of the examined remedies on the Plasmodium stages developing in the vertebrate host, thus encouraging studies aiming at identifying the active fractions and compounds responsible for the described activity and to develop standardized prophylactic remedies.
\end{abstract}

(c) 2012 Elsevier Ireland Ltd. All rights reserved.

\section{Introduction}

Burkina Faso is characterized by seasonal, intense malaria transmission. The management of the disease with modern medicines is severely compromised by a widespread presence of Plasmodium falciparum strains resistant to the most affordable drugs, like chloroquine, mefloquine, sulfadoxine-pyrimethamine (Guiguemde et al., 1994; Mueller et al., 2003; Sirima et al., 2003). In addition, many patients do not seek medical care at formal health services during their illness. Recent studies on health seeking behaviour, conducted in Nouna, a village situated in the Northwest

\footnotetext{
* Corresponding author at: Institut de Recherche en Sciences de la Santé, direction régionale de Bobo Dioulasso, Burkina Faso. Tel.: +226 71484866 .

E-mail addresses: yerbanga.rakiswende@unicam.it, yrserge@yahoo.fr (R.S. Yerbanga).
}

of Burkina Faso, showed that sick children are prevailingly treated at home by their mothers, using both modern and traditional medicine (Mueller et al., 2004; Beiersmann et al., 2007). Traditional remedies are obtained by decoction, maceration or infusion of different organs from several plant species (Karou et al., 2003; Sanon et al., 2003a,b; Hilou et al., 2006; Tapsoba and Deschamps, 2006; Traore et al., 2009). Commonly used antimalarial plants are Azadirachta indica A. Juss. (Meliaceae; Isah et al., 2003; Udeinya et al., 2006), Cochlospermum planchonii Hook.f. (Cochlospormaceae), Phyllanthus amarus Schumach. et Thonn. (Euphorbiaceae) and Cassia alata L. (Fabaceae). The latter three are also prepared as combination remedies (Benoit-Vical et al., 2003; VonthronSénécheau et al., 2003; Pousset, 2006).

Efficacy studies carried out on Azadirachta indica confirmed its antiplasmodial properties. Bark and leaf extracts from Azadirachta indica, tested in vitro on asexual blood stages of a chloroquine (CQ)-resistant and a CQ-sensitive Plasmodium falciparum strain, 
showed $\mathrm{IC}_{50}$ values of $7.29 \mu \mathrm{g} / \mathrm{ml}$ and $6.25 \mu \mathrm{g} / \mathrm{ml}$, respectively (Benoit-Vical et al., 1996). Gedunin, a limonoid isolated from active extracts of different Meliaceae plants, including Azadirachta indica (MacKinnon et al., 1997), exhibited an $\mathrm{IC}_{50}$ of $20 \mu \mathrm{g} / \mathrm{ml}$ on the CQresistant Plasmodium falciparum strain W2 (Khalid et al., 1989). An in vivo study, aimed at assessing the efficacy of tablets prepared from leaf and bark extracts, found an average parasitaemia reduction of $75.3 \%$ and $65.6 \%$, respectively on Plasmodium yoelli nigeriensis infected mice, after administration of an $800 \mathrm{mg} / \mathrm{kg}$ oral suspension (Isah et al., 2003).

A standardized Cochlospermum planchonii preparation is available in Burkina Faso since the nineties. Dried roots of the plant, collected according to traditional medicine practices and packaged in plastic bags, are marketed by a local pharmaceutical company under the name of N'Dribala (Pousset, 2006). The assessment of the antiplasmodial activity of aqueous extracts of this remedy yielded positive results: at a concentration of $4.4 \mu \mathrm{g} / \mathrm{ml}$ the in vitro growth of Plasmodium falciparum blood stages (K1 CQ-resistant strain) was inhibited by $50 \%$ (Vonthron-Sénécheau et al., 2003). Moreover, evidence on N'Dribala therapeutic efficacy emerged from a clinical study conducted on adults, in which $90 \%$ of patients treated with the infusion for 5 days $(3 \times 200 \mathrm{ml}$ per day) were found asymptomatic at the end of the treatment course and 52\% had no detectable parasitaemia at microscopy (Benoit-Vical et al., 2003). Finally, the same pharmaceutical company is also marketing the antimalarial Saye, a combination remedy prepared from Cochlospermum planchonii roots, Cassia alata leaves and Phyllanthus amarus whole plant. The antiplasmodial properties of this remedy were tested by administering to parasitaemic mice, infected with Plasmodium berghei, decoctions of Saye, which reduced parasitaemia by $74.15 \%$ at the dose of $250 \mathrm{mg} / \mathrm{kg}$. In vitro assessments on Plasmodium falciparum blood stage cultures (3D7 chloroquine sensitive strain), however, showed only a moderate activity by the extract $\left(\mathrm{IC}_{50}=80.11 \mu \mathrm{g} / \mathrm{ml}\right.$; Traoré et al., 2008).

The spread of multi-resistant Plasmodium falciparum strains and the emergence of Anopheles genotypes resistant to the available insecticides constitute an enormous threat to the control of malaria. Therefore, new knowledge, products and measures and in particular new chemotherapeutic tools are urgently needed. Traditional malaria treatments are a promising source for the discovery of new antimalarials. In Africa, more than $80 \%$ of people use traditional medicines and most families resort to plant based medicines for the cure of malaria patients (WHO, 2002). A substantial amount of knowledge on antimalarial plants, their preparation, use and toxicity risks is already available to the scientific community thanks to ethnopharmacological investigations conducted in different African settings (Sanon et al., 2003a; Willcox and Bodeker, 2004; Soh and Benoit-Vical, 2007; Jansen et al., 2010). Moreover, evidence on traditional prophylactic use of antimalarial plants is also available, though from a much more limited number of studies (Ramakrishna et al., 1989; Traoré et al., 1992; Daffe, 2005). Thus, traditional medicine could be exploited not only for the development of new or improved curative treatments, but also for the design of plant based tools to prevent the disease and reduce its transmission in communities. During the malaria transmission season, mass administration of prophylactic-transmission blocking remedies, active against the asexual blood stages of the parasite and against the sexual stages developing in the vector may be a cost-effective approach to complement current malaria control endeavours.

The aim of this study was to verify whether the antiplasmodial properties of medicinal plants used traditionally for the treatment of malaria in Burkina Faso, in particular Saye, N'Dribala and Azadirachta indica extracts, can be exploited for developing standardized prophylactic, remedy-based protocols, targeting both the parasite stages responsible for the disease and those thriving within the mosquito vector.

\section{Materials and methods}

\subsection{The Plasmodium berghei/Anopheles stephensi/BALB/c mouse system}

The Anopheles stephensi colony was maintained at $30^{\circ} \mathrm{C},>95 \%$ $\mathrm{RH}$ and a photoperiod of $12 \mathrm{~h}$. BALB/c mice were bred in the animal facility of the University of Camerino, Italy. Mosquitoes took their blood meals on mice anaesthetized using a mixture of 1 volume of Rompun (xylazin 2\%), 1 volume of Prequillan (acepromazine, $10 \mathrm{mg}$ ) and 3 volumes of PBS, $\mathrm{pH} 7.2$, at $0.05 \mathrm{ml} / 10 \mathrm{~g}$ body weight. Experimental animal rearing and handling were fully compliant with the Italian Directive 116 of 10/27/92 on the "use and protection of laboratory animals", and in adherence with the European regulation $86 / 609$ of $11 / 24 / 86$ (licence no. $125 / 94 \mathrm{~A}$, issued by the Italian Ministry of Health).

The Plasmodium berghei ANKA (CQ-sensitive) strain was maintained by weekly blood transfer from infected to healthy mice. Every second month a cyclic passage was carried out by infecting mosquitoes through a blood meal on gametocytaemic mice and, 3 weeks later, by infecting naive mice through the bites of sporozoite carrying mosquitoes. Mosquitoes infected with Plasmodium berghei were kept at $19 \pm 1^{\circ} \mathrm{C}$ for the whole duration of the sporogonic cycle.

\subsection{Plant extract preparation}

Ripe fruits from Azadirachta indica A. Juss. (Meliaceae) were collected in Ziniaré, a village in the central region of Burkina Faso, in June 2008. The tree was identified by Prof. Jeanne Millogo, professor of Botanics at the Life Science Unit (University of Ouagadougou), and a voucher specimen ( $\mathrm{N}^{\circ} 2 \mathrm{NFE}$ ) has been deposited in the Laboratory of Ecology at the University of Ouagadougou. Neem fruits (NF) were dried in the laboratory at room temperature, powdered and stored in dark and dry conditions. Twenty grams of NF were then macerated for $24 \mathrm{~h}$ in $200 \mathrm{ml}$ of ethanol and freeze-dried.

Saye and N'Dribala ('Laboratoire Phytofla', Banfora, Burkina Faso) were purchased from a pharmacy and infusions were prepared according to the indications provided by the manufacturer: $100 \mathrm{~g}$ of product was extracted with $750 \mathrm{ml}$ of boiling water for $5 \mathrm{~min}$, cooled down, and then freeze-dried.

\subsection{Prophylactic assay}

The prophylactic assay protocol was developed to match the traditional plant extract preparation, as practiced in Ziniaré, a village situated $35 \mathrm{~km}$ north of Ouagadougou, for the prevention of malaria during the rainy season (personal observation YRS): two handfuls of raw plant material $(\sim 170 \mathrm{~g})$ are boiled with one bottle and half of water $(\sim 1500 \mathrm{ml})$ for $5 \mathrm{~min}$. The dose for an adult is one small bottle of the decoction $(\sim 50 \mathrm{cl})$ daily for three days, repeated every 2-3 weeks during the period of high malaria transmission. For children, the dose is half of that for adults. Assuming a $22 \%$ extraction yield and setting the weight of an adult to approximately $60 \mathrm{~kg}$, the daily dose taken by villagers can be estimated at about $200 \mathrm{mg}$ of lyophilized extract $/ \mathrm{kg}$ body weight.

For the experiments, Saye and N'Dribala lyophilized extracts were dissolved in distilled water and NF extract was dissolved in PBS pH 7.2, with 1\% ethanol. Six mice (females weighing 18-20 g) were used per treatment group. Mice were treated orally with $200 \mu \mathrm{l}$ of experimental solutions, corresponding to a $100 \mathrm{mg} / \mathrm{kg}$ extract dose. Control animals received the relevant solvents. The treatments were given twice a day for 9 days, starting two days 
before the infection (day -2) and ending one week after it (day +7 ). Mice were challenged by exposing them to infectious mosquito bites on day $0,1 \mathrm{~h}$ after the first treatment of that day. The anesthetized treated and control mice were placed individually on the top of cages containing 20 mosquitoes taken from batches with an infection prevalence $>95 \%$. Mosquito infection was routinely determined by counting oocysts on dissected midguts on day 10 after an infectious blood meal. After having received at least 10 bites, mice were removed and returned to their respective cages. Parasite density was determined on Giemsa-stained thin blood smears, sampled from the tail of the mice at day +7 . To estimate extract impact on asexual blood forms percent parasitaemia was calculated. The effect on gametocytaemia was assessed by estimating the ratio between the number of gametocytes and the number of infected red blood cells per $\mu$ l of blood. Infected red blood cells per $\mu \mathrm{l}$ blood (IRBCs $/ \mu \mathrm{l}$ ) were determined by using the following proportion: [(IRBC counted in 25 fields $) /($ IRBC $/ \mu \mathrm{l})]=[($ counted WBC in 25 fields $\left.) /\left(13 \times 10^{3}\right)\right]$, considering $13 \times 10^{3}$ the average number of white blood cells (WBC) per $\mu$ l of BALB/c mouse blood. The density of the sexual stages of the parasite (macrogametocytes, MGs, and microgametocytes, $\mathrm{mGs}$ ) was calculated in the same way. Data were expressed as arithmetic means \pm confidence intervals at the $95 \%$ level and the Student's $t$-test was used to compare treated and control group means.

The prophylaxis experiments were performed twice with each extract.

\subsection{Transmission blocking test}

Experimental mice were infected by intraperitoneal (i.p.) inoculation of $10^{7}$ infected red blood cells and, four days after infection, the presence of mature gametocytes was verified on Giemsa stained blood smears. Three gametocytaemic mice were used for each experimental group. Mice received a single i.p. inoculation of $100 \mu \mathrm{l}$ of test solutions at a dose of $50 \mathrm{mg} / \mathrm{kg}$ or were administered control solvents. Sixty minutes after the treatment, the animals were narcotized as described above and placed, individually, over cages containing about 200, 5-7-day old Anopheles stephensi females. Females were allowed to feed for a period of $45 \mathrm{~min}$. Unfed mosquitoes were discarded the next day. Ten days after the blood meal, samples of about 75 mosquito females per treatment group were dissected ( 25 mosquitoes from each of the 3 replicate cages) and their midguts examined under the light microscope $(400 \times)$ to assess oocyst presence and count their number.

\section{Results}

\subsection{Prophylactic activity}

Proliferation of blood stage parasites was reduced in mice under prophylactic regimen, with respect to control animals. On day 7 after the challenge, the average parasitaemia was $8.5 \%$ for NF and $7.5 \%$ for Saye, compared to $15.2 \%$ in controls. In N'Dribala treated mice, a mean parasitaemia of $9 \%$ was observed, whereas the value of the respective control mice amounted to $16.5 \%$. The observed differences were significant $(P<0.001)$ for all the treatment groups (Table 1$)$. The percentages of parasitaemia reduction calculated from the replicates were 52.0\% ( $\left.\mathrm{Cl}_{95} 46.1-57.9\right), 45.5 \%$ $\left(\mathrm{Cl}_{95} 44.5-46.5\right)$ and $45.0 \%\left(\mathrm{Cl}_{95} 41.1-48.9\right)$ for Saye, N'Dribala, and NF, respectively. Similarly, numbers of MG and $\mathrm{mG}$ per $\mu$ l of blood measured in mice that have been treated with the extracts, amounted to about half of the control values (Table 2 ). To estimate whether these lowered gametocyte densities were indicative for a gametocytocidal activity of the extracts or were reflecting the reduced schizogonic replication, the percentages of MG and $\mathrm{mG}$ on infected red blood cells (IRBCs) were calculated. As it emerges from Table 2, the values for treated mice were not replicably different from controls, ranging irrespectively between $0.4 \%$ and $1.6 \%$ for MGs and between $0.2 \%$ and $0.6 \%$ for $\mathrm{mGs}$, supporting the absence of extract effects targeted to gametocytes. The treatment was well tolerated by all mice; no mortality or signs of illness were recorded during the 9 days of treatment.

\subsection{Transmission blocking activity}

Saye, NF and N'Dribala did not show any transmission blocking activity in our experiments. Similar oocyst numbers were observed in mosquitoes fed on extract-treated gametocytaemic mice compared to controls, ranging from an average of 50 to 150 oocysts per cage in both groups (Table 3 ).

\section{Discussion}

This study demonstrated the prophylactic potential of the remedies Saye, N'Dribala and of a neem preparation used in Burkina Faso as traditional antimalarials, in the murine malaria parasite Plasmodium berghei. The prophylactic assays evidenced that the 3 remedies were able to reduce parasitaemia by about one half of the values recorded in control mice.

In a previous study, employing a curative protocol (Peter's 4 day test), a Saye extract reduced parasitaemia in Plasmodium berghei infected mice by $74 \%$, following treatment with a single dose of $250 \mathrm{mg} / \mathrm{kg}$ (Traoré et al., 2008). The present study shows that by administering half of that dose and starting the treatment two days before challenge with infective mosquito bites, a parasitaemia reduction of $52 \%$ can be achieved.

In the case of N'Dribala, data are available from a field trial carried out on adults in Burkina Faso (Benoit-Vical et al., 2003), in which the remedy showed a moderate efficacy in clearing parasitaemia and a high capacity of reducing clinical signs: on day 5 of treatment ( $200 \mathrm{ml}$ of decoction, 3 times per day), $52 \%$ of N'Dribalatreated patients, compared to $57 \%$ of chloroquine-treated patients, had Plasmodium falciparum negative slides, but more than $90 \%$ of study subjects of both groups declared to be symptom free. It is difficult to estimate to what extent these outcomes were determined by acquired immunity of the adult study population and to what extent by antimalarial activity of the remedy. Our results with N'Dribala in the murine malaria system could be considered as a proof of principle of the remedy's antiplasmodial properties in vivo.

Several in vitro and in vivo studies have investigated the antiplasmodial activity of leaves, bark and seeds of the neem tree, Azadirachta indica, demonstrating that the antimalarial activity of these plant parts can be attributed mainly to the molecule gedunin, but also to some other limonoids such as nimbinin and nimbolide (Khalid et al., 1989; Bray et al., 1990; MacKinnon et al., 1997). An in vitro study performed by MacKinnon et al. (1997) on Plasmodium falciparum W2 (CQ-resistant) strain, showed that gedunin, with its $\mathrm{IC}_{50}$ of $20.0 \mathrm{ng} / \mathrm{ml}$, was more active than quinine $\left(\mathrm{IC}_{50}=34.9 \mathrm{ng} / \mathrm{ml}\right)$. However, pure gedunin did not show activity when tested in vivo in the Plasmodium berghei murine malaria parasites (Omar et al., 2003).

Analysing neem fruits collected in Burkina Faso, we identified several triterpenoids in this plant part, that exhibited antiplasmodial activity in vitro, inhibiting the proliferation of Plasmodium falciparum (D10 chloroquine-sensitive and W2 chloroquineresistant strain) blood stages (Chianese et al., 2010). The most active molecules were the 3 limonoids, azadirone, gedunin, and neemfruitin A showing $\mathrm{IC}_{50}$ values of $1.21 \pm 0.30 \mu \mathrm{M}, 1.31 \pm 0.42 \mu \mathrm{M}$ and $1.74 \pm 0.25 \mu \mathrm{M}$, respectively (W2 strain). Interestingly, the EtOAc 
Table 1

Prophylactic effect of NF, Saye and N'Dribala on mice infected with Plasmodium berghei ANKA strain.

\begin{tabular}{|c|c|c|c|c|}
\hline Treatment ${ }^{\mathrm{a}}$ & Experiment ${ }^{\mathrm{b}}$ & $\begin{array}{l}\text { Average no. of infective } \\
\text { bites per mouse }\end{array}$ & $\begin{array}{l}\text { Parasitaemia }{ }^{c} \\
\left(\mathrm{Cl}_{95} \%\right)\end{array}$ & $\begin{array}{l}\% \text { reduction of parasitaemia } \\
\text { with respect to controls }\end{array}$ \\
\hline \multirow[t]{2}{*}{ NF } & 1 & 11.2 & $8.0(7.03-8.97)$ & 43 \\
\hline & 2 & 10.8 & $9.0(8.03-9.97)$ & 47 \\
\hline \multirow[t]{2}{*}{ Saye } & 1 & 11.3 & $7.0(6.40-7.60)$ & 49 \\
\hline & 2 & 11.2 & $8.0(6.69-9.31)$ & 55 \\
\hline \multirow[t]{2}{*}{ Control } & 1 & 11.2 & $13.5(12.40-14.60)$ & - \\
\hline & 2 & 10.8 & $17.0(14.29-19.71)$ & - \\
\hline \multirow[t]{2}{*}{ N'Dribala } & 3 & 11.5 & $9.0(7.22-10.78)$ & 46 \\
\hline & 4 & 13.3 & $9.0(7.82-10.18)$ & 45 \\
\hline \multirow[t]{2}{*}{ Control } & 3 & 10.8 & $17.0(14.29-19.71)$ & - \\
\hline & 4 & 13.0 & $16.0(14.18-17.82)$ & - \\
\hline
\end{tabular}

a NF: neem fruit; Saye: roots of Cochlospermum planchonii combined with Cassia alata and Phyllanthus amarus; N'Dribala: roots of Cochlospermum planchonii.

b Each number corresponds to one experiment involving different treatment groups of six mice each.

c Average percent parasitaemia on day 7 after the challenge.

Table 2

Effect of NF, Saye and N'Dribala treatments on gametocytaemia.

\begin{tabular}{|c|c|c|c|c|c|}
\hline Treatment & Exp. & $\mathrm{MG} / \mu \mathrm{l} \times 10^{3}\left(\mathrm{Cl}_{95} \%\right)$ & $\mathrm{mG} / \mu \mathrm{l} \times 10^{3}\left(\mathrm{Cl}_{95} \%\right)$ & MG/IRBC (\%) $\left(\mathrm{Cl}_{95} \%\right)$ & $\mathrm{mG} / \operatorname{IRBC}(\%)^{\mathrm{a}}\left(\mathrm{Cl}_{95} \%\right)$ \\
\hline \multirow[t]{2}{*}{ NF } & 1 & $3.29(2.19-4.56)^{\dagger}$ & $1.64(0.73-2.73)^{\dagger}$ & $0.80(0.60-1.00)^{\dagger}$ & $0.39(0.20-0.60)^{\dagger}$ \\
\hline & 2 & $4.73(2.70-5.93)^{\S}$ & $0.94(0-0.98)^{\S}$ & $1.00(0.60-1.20)^{\dagger}$ & $0.19(0-0.20)^{\S}$ \\
\hline \multirow[t]{2}{*}{ Saye } & 1 & $2.44(1.17-3.79)^{\dagger}$ & $1.22(1.17-2.53)^{\dagger}$ & $0.40(0.20-0.60)^{\dagger}$ & $0.19(0.20-0.40)^{\dagger}$ \\
\hline & 2 & $6.99(3.38-9.56)^{\S}$ & $1.16(0-2.39)^{\dagger}$ & $1.19(0.60-1.60)^{\dagger}$ & $0.19(0-0.40)^{\S}$ \\
\hline \multirow[t]{2}{*}{ Control } & 1 & $7.05(4.36-7.52)$ & $2.35(0-5.01)$ & $0.59(0.40-0.60)$ & $0.19(0-0.40)$ \\
\hline & 2 & $11.81(6.93-17.23)$ & $2.95(2.77-4.70)$ & $1.60(1.00-2.20)$ & $0.39(0.40-0.60)$ \\
\hline \multirow[t]{2}{*}{ N'Dribala } & 3 & $7.98(6.71-10.53)^{\dagger}$ & $3.42(1.11-4.68)^{\dagger}$ & $1.40(1.20-1.80)^{\dagger}$ & $0.60(0.20-0.80)^{\dagger}$ \\
\hline & 4 & $1.32(0.64-2.04)^{\dagger}$ & $0.66(0-1.36)^{\dagger}$ & $0.40(0.20-0.60)^{\dagger}$ & $0.19(0-0.40)^{\dagger}$ \\
\hline \multirow[t]{2}{*}{ Control } & 3 & $11.81(6.93-17.23)$ & $4.43(2.77-4.70)$ & $1.60(1.00-2.20)$ & $0.60(0.40-0.60)$ \\
\hline & 4 & $5.20(3.34-9.10)$ & $1.74(0-3.64)$ & $0.59(0.40-1.00)$ & $0.19(0-0.40)$ \\
\hline
\end{tabular}

a Average percent gametocytes per IRBCs.

$\dagger P$-value $\geq 0.05$.

$\S P$-value $<0.05$.

(ethanolacetate) and $\mathrm{BuOH}$ (butanol) fraction of the fruit showed similarly high activity ( IC $_{50} 1.92 \pm 0.84 \mu \mathrm{g} / \mathrm{ml}$ on W2 strain). Given the relatively low abundance of highly active limonoids in these extracts, this remarkable activity cannot be explained on the basis of additive effects, but a synergistic action should be taken into account (Chianese et al., 2010). The presented in vivo study demonstrates that the antiplasmodial activity of the limonoids contained in the fruit extract is conserved in the vertebrate host of the parasite and comparing our results with those on gedunin in the in vivo study of Omar et al. (2003), it provides supporting evidence for the importance of synergistic action amongst antiplasmodial limonoids also in vivo.

The antiplasmodial activity detected here with all three remedies appeared to be restricted to the asexual parasite development

Table 3

Effect of treatment on oocyst prevalence and density on mosquito midguts.

\begin{tabular}{|c|c|c|c|c|}
\hline Treatment & Experiment & $\begin{array}{l}\text { Mosquito } \\
\text { replicate cage }\end{array}$ & $\begin{array}{l}\% \text { oocyst positive } \\
\text { mosquitoes }\left(\mathrm{IC}_{95}\right)\end{array}$ & Oocysts/mosquito $\left(\mathrm{IC}_{95}\right)^{\mathrm{c}}$ \\
\hline NF & 1 & $\begin{array}{l}1 \\
2 \\
3\end{array}$ & $\begin{array}{l}96(95-97) \\
92(91-93) \\
96(95-97)\end{array}$ & $\begin{array}{r}105(70-141) \\
130(97-162) \\
88(34-122)\end{array}$ \\
\hline Saye & 1 & $\begin{array}{l}1 \\
2 \\
3\end{array}$ & $\begin{array}{r}100 \\
96(95-97) \\
88(87-89)\end{array}$ & $\begin{array}{r}116(84-148) \\
83(38-129) \\
150(110-190)\end{array}$ \\
\hline Control $^{\mathrm{a}}$ & 1 & $\begin{array}{l}1 \\
2 \\
3\end{array}$ & $\begin{array}{r}100 \\
80(79-81) \\
88(87-89)\end{array}$ & $\begin{array}{r}163(120-205) \\
60(15-106) \\
103(59-147)\end{array}$ \\
\hline N'Dribala & 2 & $\begin{array}{l}1 \\
2 \\
3\end{array}$ & $\begin{array}{r}100 \\
93(92-94) \\
100\end{array}$ & $\begin{array}{r}88(69-106) \\
101(76-125) \\
69(41-98)\end{array}$ \\
\hline Control $^{\mathrm{b}}$ & 2 & $\begin{array}{l}1 \\
2 \\
3\end{array}$ & $\begin{array}{r}91(90-92) \\
91(90-92) \\
100\end{array}$ & $\begin{array}{r}97(66-128) \\
55(36-75) \\
100(75-124)\end{array}$ \\
\hline
\end{tabular}

\footnotetext{
a Control for Saye and NF.

b Control for N'Dribala.

c Geometric means from the 25 examined mosquitoes/cage, only positive samples were included.
} 
in the vertebrate host. The decrease of the number of micro- and macrogametocytes in the blood of treated mice, similar to the approximate $50 \%$ reduction observed on parasitaemia, most likely reflects the impact on the schizogonic cycle and not a direct effect on gametocyte development. Furthermore, the transmission blocking experiments did not reveal any effects on the parasite stages maturing in the anopheline vector. In a previous study conducted with an azadirachtin rich neem seed extract, we found a complete block of parasite transmission in mosquitoes after having fed on gametocytaemic mice treated with the product at an azadirachtin concentration of $50 \mathrm{mg} / \mathrm{kg}$ mouse body weight (Lucantoni et al., 2010). This transmission blocking effect can be attributed to the molecule azadirachtin that is able to interfere with microgametocyte exflagellation (Billker et al., 2002) and ookinete formation in the mosquito mid gut lumen (Lucantoni et al., 2010). The tested neem fruit extract does not contain azadirachtin at a detectable level. Thus, azadirachtin remains the only limonoid molecule for which antiplasmodial activity against parasite stages developing in the vector have been demonstrated. The antiplasmodial activity of azadirone, gedunin and neemfruitin A, present in the neem fruit extract, appears to be restricted to the stages developing in the vertebrate host.

\section{Conclusion}

Saye, N'Dribala and the neem tree are widely available and commonly used as antimalarial remedies by the population of Burkina Faso, clinical field trials should be encouraged to verify whether these affordable remedies may contribute to reducing the malaria burden in the communities, particularly in rural settings. Such trials should address both the curative efficacy and the prophylactic potential of these remedies, employing study designs that allow to assess an impact at community level in terms of malaria incidence and intensity of transmission.

For the benefit of the large proportion of African population who adheres to the traditional medicine practices, there is an urgent need to identify, characterize and validate the commonly used antimalarial remedies. Ethnobotanical and ethnomedical studies should be promoted in different settings to catalogue the plants, collect information on their preparations and mode of use, to conserve this knowledge for future generations. Extracts prepared according to the practitioners recipes should be screened not only for curative but also for prophylactic and transmission blocking activity and, most important, for toxicity risks. Socio-economic issues also need to be addressed, investigating on costs of, accessibility to, and compliance with traditional remedies compared to currently adopted modern combination therapies. However, to what extent such endeavours will be fruitful and impact on malaria burden in the future, is basically depending on the capacity of both, modern scientists and traditional medicine practitioners in trusting and respecting each other.

\section{Acknowledgements}

To my colleagues, post-doctoral collaborators, technical staff, I express my sincere thanks. The work was financially supported by the University of Camerino (UNICAM), the Italian Malaria Network, the Seventh European Framework Programme project 'TransMalariaBloc' n. 223736 and by the UNICAM PhD Programme on Malaria and Human Development (supported by WHO Global Malaria Programme).

\section{References}

Beiersmann, C., Sanou, A., Wladarsch, E., De Allegri, M., Kouyaté, B., Müller, O., 2007. Malaria in rural Burkina Faso: local illness concepts, patterns of traditional treatment and influence on health-seeking behaviour. Malaria Journal 6, 106.
Benoit-Vical, F., Valentin, A., Da, B., Dakuyo, Z., Descamps, L., Mallié, M., 2003. N'Dribala (Cochlospermum planchonii) versus chloroquine for treatment of uncomplicated Plasmodium falciparum malaria. Journal of Ethnopharmacology 89, 111-114.

Benoit-Vical, F., Valentin, A., Pelissier, Y., Marion, C., Castel, D., Milhau, M., Mallie, M., Bastide, J.M., Diafouka, F., Kone-Bamba, D., Malan, A., Kone, M., Loukou, Y., Monet, D., Ake-Assi, L., Yapo, A., 1996. Confirmation, in vitro, de l'activité antimalarique de certaines plantes d'origine africaine utilisées en médecine traditionnelle. Médecine d'Afrique Noire 7, 43.

Billker, O., Shaw, M.K., Jones, I.W., Ley, S.V., Mordue, A.J., Sinden, R.E., 2002. Azadirachtin disrupts formation of organised microtubule arrays during microgametogenesis of Plasmodium berghei. Journal of Eukaryotic Microbiology 49, 489-497.

Bray, D.H., Warhurst, D.C., Connolly, J.D., O'Neill, M.J., Phillipson, J.D., 1990. Plants as source of antimalarial drug. Part 7. Activity of some species of Meliaceae plants and their constituent limoids. Phytotherapy Research 4, 29-35.

Chianese, G., Yerbanga, S.R., Lucantoni, L., Habluetzel, A., Basilico, N., Taramelli, D., Fattorusso, E., Taglialatela-Scafati, O., 2010. Antiplasmodial triterpenoids from the fruits of neem, Azadirachta indica. Journal of Natural Products 73, 1448-1452.

Daffe, S., 2005. Connaissances attitudes et pratiques des populations face au paludisme dans l'aire de sante de finkolo (sikasso) Mali. Thèse de Doctorat d'Etat Faculté de Médecine, de Pharmacie et d'Odonto-Stomatologie-Université de Bamako (Mali).

Guiguemde, T.R., Aouba, A., Ouedraogo, J.B., Lamizana, L., 1994. Ten-year surveillance of drug-resistant malaria in Burkina Faso (1982-1991). American Journal of Tropical Medicine and Hygiene 50, 699-704.

Hilou, A., Nacoulma, O.G., Guiguemde, T.R., 2006. In vivo antimalarial activities of extracts from Amaranthus spinosus L. and Boerhaavia erecta L. in mice. Journal of Ethnopharmacology 103, 236-240.

Isah, A.B., Ibrahim, Y.K., Iwalewa, E.O., 2003. Evaluation of the antimalarial properties and standardization of tablets of Azadirachta indica (Meliaceae) in mice. Phytotherapy Research 17, 807-810.

Jansen, O., Angenot, L., Tits, M., Nicolas, J.P., De Mol, P., Nikiéma, J.B., Frédérich, M., 2010. Evaluation of 13 selected medicinal plants from Burkina Faso for their antiplasmodial properties. Journal of Ethnopharmacology 130, 143-150.

Karou, D., Dicko, M.H., Sanon, S., Simpore, J., Traore, A.S., 2003. Antimalarial activity of Sida acuta Burm. f. (Malvaceae) and Pterocarpus erinaceus Poir. (Fabaceae). Journal of Ethnopharmacology 89, 291-294.

Khalid, S.A., Duddeck, H., Gonzales-Sierra, M., 1989. Isolation and characterization of an antimalarial agent of the Neem tree Azadirachta indica. Journal of Natural Products 52, 922-926.

Lucantoni, L., Yerbanga, R.S., Lupidi, G., Pasqualini, L., Esposito, F., Habluetzel, A., 2010. Transmission blocking activity of a standardized neem (Azadirachta indica) seed extract on the rodent malaria parasite Plasmodium berghei in its vector Anopheles stephensi. Malaria Journal 9, 66.

MacKinnon, S., Durst, T., Arnason, J.T., Angerhofer, C., Pezzuto, J., Sanchez-Vindas, P.E., Poveda, L.J., Gbeassor, M., 1997. Antimalarial activity of tropical Meliaceae extracts and gedunin derivatives. Journal of Natural Products 60, 336-341.

Mueller, O., Traoré, C., Kouyaté, B., 2003. Clinical efficacy of chloroquine in young children with uncomplicated malaria-a community based study in rural Burkina Faso. Tropical Medicine and International Health 8, 202-203.

Mueller, O., Razum, O., Traore, C., Kouyate, B., 2004. Community effectiveness of chloroquine and traditional remedies in the treatment of young children with falciparum malaria in rural Burkina Faso. Malaria Journal 3, 36.

Omar, S., Zhang, J., MacKinnon, S., Leaman, D., Durst, T., Philogene, B.J., Arnason, J.T., Sanchez-Vindas, P.E., Poveda, L., Tamez, P.A., Pezzuto, J.M., 2003. Traditionallyused antimalarials from the Meliaceae. Current Topics in Medicinal Chemistry 3, 133-139.

Pousset, J.L., 2006. Place des médicaments traditionnels en afrique. Medécine Tropical 66, 606-609.

Ramakrishna, J.W.R., Brieger, W.R., Adeniyi, J.D., 1989. Treatment of malaria and febrile convulsions. An educational diagnosis of Yoruba beliefs. International Quarterly Community Health Education 9, 305-319.

Sanon, S., Ollivier, E., Azas, N., Mahiou, V., Gasquet, M., Ouattara, C.T., Nebie, I., Traore, A.S., Esposito, F., Balansard, G., Timon-David, P., Fumoux, F., 2003a. Ethnobotanical survey and in vitro antiplasmodial activity of plants used in traditional medicine in Burkina Faso. Journal of Ethnopharmacology 86, 143-147.

Sanon, S., Azas, N., Gasquet, M., Ollivier, E., Mahiou, V., Barro, N., Cuzin-Ouattara, N., Traore, A.S., Esposito, F., Balansard, G., Timon-David, P., 2003b. Antiplasmodial activity of alkaloid extracts from Pavetta crassipes (K. Schum) and Acanthospermum hispidum (DC), two plants used in traditional medicine in Burkina Faso. Parasitology Research 90, 314-317.

Soh, P.N., Benoit-Vical, F., 2007. Are West African plants a source of future antimalarial drugs. Journal of Ethnopharmacology 114, 130-140.

Sirima, S.B., Tiono, A.B., Konate, A., Diarra, A., Castelli, F., Pinoges, L., Mugittu, K., Taylor, W.R., Olliaros, P.L., 2003. Efficacy of artesunate plus chloroquine for the treatment of uncomplicated malaria in children in Burkina Faso: a doubleblind, randomized, controlled trial. Transactions of the Royal Society of Tropical Medicine and Hygiene 97, 345-349.

Tapsoba, H., Deschamps, J.P., 2006. Use of medicinal plants for the treatment of oral diseases in Burkina Faso. Journal of Ethnopharmacology 104, 68-78.

Traore, A., Derme, A.I., Sanon, S., Gansane, A., Ouattara, Y., Nebie, I., Sirima, S.B., 2009. Connaissances ethnobotaniques et pratiques phytothérapeutiques des tradipraticiens de santé de la Comoé pour le traitement du paludisme: processus d'une recherche scientifique de nouveaux antipaludiques au Burkina faso. Etnopharmacologia 43, 35-46. 
Traoré, M., Diallo, A., Nikièma, J.B., Tinto, H., Dakuyo, Z.P., Ouédraogo, J.B., Guissou, I.P., Guiguemdé, T.R., 2008. In vitro and in vivo antiplasmodial activity of 'Saye', an herbal remedy used in Burkina Faso traditional medicine. Phytotherapy Research 22, 550-551.

Traoré, S., Coulibaly, S.O., Sidibé, M.C., 1992. Comportement et coûts liés au paludisme chez les femmes des campements des pêcheurs dans la zone de Sélingué au Mali. INRSP, Bamako CD - INSAH L15040.

Udeinya, J., Brown, N., Shu, E.N., Udeinya, F.I., Quakeyie, I., 2006. Fractions of an antimalarial neem-leaf extract have activities superior to chloroquine, and are gametocytocidal. Annals of Tropical Medicine and Parasitology 100, 17-22.
Vonthron-Sénécheau, C., Weniger, B., Ouattara, M., Tra Bi, F., Kamenan, A., Lobstein, A., Brun, R., Anton, R., 2003. In vitro antiplasmodial activity and cytotoxicity of ethnobotanically selected Ivorian plants. Journal of Ethnopharmacology 87 221-225.

WHO (World Health Organization) Centre for Health Development, 2002. Traditional medicine: planning for cost-effective traditional health services in the new century-a discussion paper. http://www.who.or.jp/tm/research/.

Willcox, M., Bodeker, G., 2004. Frequency of use of traditional herbal medicines for the treatment and prevention of malaria: an overview of the literature. In Willcox, M., Bodeker, G., Rasoanaivo (Eds.), Traditional Medicinal Plants and Malaria. CRC Press LLC, pp. 161-185. 